\title{
David A. Vila The Diminution of the Classical Column: Domini Visual Sensibility in Antiquity and the Renaissance
}

David Vila Domini looks at the recommendations regarding optical adjustment of the columnar diminution in the architectural treatises of Vitruvius, Alberti, and Palladio. He examines the variation in diminution of column thickness according to the height of the column, and its implications for our understanding of the various practices with regard both to columnar proportion and visual sensibility in Antiquity and the Renaissance. He also examines possible sources for the methods by which the ratios of column height to diameter were derived.

\section{Introduction $^{1}$}

Writing some time around the 1450s [Grayson 1960], Alberti composed his ten-book treatise on architecture De re aedificatoria, basing it largely on the ancient Roman tract De architectura [Krautheimer 1963], which its author, Vitruvius, dedicated to the emperor Augustus. Alberti and his contemporaries found Vitruvius's text inelegantly written, often obscure and in some passages entirely unintelligible. ${ }^{2}$ The widespread use of Greek terms for things that were otherwise nameless in Augustan Latin confounded the efforts of the humanists trying to make sense of the only text on architecture that had survived from the antiquity they had so much come to admire. In his attempt to remedy these linguistic problems, Alberti was forced to introduce neologisms in order to express ideas for which, until then, there were no words in Latin. ${ }^{3}$ But the difficulties were by no means exclusively linguistic, and constitute an indication of the very different understanding that Roman Antiquity and the Early Renaissance had of architecture.

Despite the criticisms that Alberti made of Vitruvius, a large amount of the detailed information that he provides is directly transcribed from the older treatise. For example, although the actual proportions of the columnar orders ${ }^{4}$ as described in De re aedificatoria do not entirely coincide with those given by Vitruvius-Alberti claims to have derived these from his own survey of Roman ruins ${ }^{5}$ - the modular systems which describe how to lay out the design for temple facades are taken from De architectura. ${ }^{6}$

Close correspondences between the two treatises are frequent, and it would seem correct in principle to assume that Alberti took from Vitruvius what he considered to be of relevance in some way to the kind of architecture that he was promoting. This pattern of borrowing from earlier written works was to continue through the proliferation of architectural treatises, including Palladio's Quattro Libri, where the subject of columnar proportions is treated in detail. 



Fig. 1. Corinthian column showing diminution, from Vitruvius 1987, LAMINA XXXII 
This paper proposes to look at one of those instances in which the three treatises run in parallel. The particular point I shall discuss is the recommendations regarding optical adjustment of the columnar diminution. In other words, the variation in diminution of column thickness according to the height of the column, and its implications for our understanding of the various practices with regard both to columnar proportion and visual sensibility in Antiquity and the Renaissance.

The classical column traditionally comprises three elements: the base, the shaft and the capital. These take different forms according to the order to which they belong, Tuscan, Doric, Ionic, Corinthian, or Composite. ${ }^{7}$ Although Alberti discusses the Tuscan temple in his treatise, he never mentions a column that would correspond to this order. ${ }^{8}$ The base is absent in the Greek Doric, and its capital is almost seamlessly developed from the shaft, but most other columns conform to the base, shaft and capital schema. ${ }^{?}$

The column shaft ${ }^{10}$ is an approximately cylindrical, vertical element which is wider at the bottom than at the top. This narrowing of the column at the top or, to be more precise, the difference or ratio between the bottom and top diameters of the column shaft, is termed the diminution. ${ }^{11}$ The profile of the shaft rarely, if ever, runs in a single straight line, and in general, will have a kind of collar projecting just below the capital, and another projection where it meets the base-Greek Doric columns lacking this lower projection. Most of the length of the shaft between the extreme projections has a profile in the shape of a slight curve, which gives rise to a swelling, or entasis, ${ }^{12}$ beginning somewhere below the centre of the shaft. For the purposes of the present discussion, I shall ignore the exact shape of the profile of the shaft. It is sufficient to bear in mind two diameters, the bottom diameter and the top diameter.

\section{The Sources}

The relevant texts concerning the diminution in the shafts of columns can be found in Vitruvius's De architectura III.iii (Fig. 1), Alberti's De re aedificatoria VII.vi (Fig. 2), and Palladio's Quattro Libri I.xiii (Fig. 3). The three passages follow in English translation under their respective author's headings, each accompanied by a brief commentary on their main traits and differences.

\section{Vitruvius}

The angle columns also must be made thicker by the fiftieth part of their diameter, because they are cut into by the air and appear more slender to the spectators. Therefore what the eye cheats us of, must be made up by calculation. The contractions, however, in the topmost necking of the columns, it seems, should be so made that from the smallest dimension up to fifteen feet, the lowest diameter should be divided into six parts and the top should be of five of those parts. Also in those which shall be from fifteen feet to twenty feet, the lowest part of the shaft is to be divided into six and a half parts; and of those parts five and a half are to be the upper diameter of the column. Also in those which shall be from twenty feet to thirty feet, let the lowest part of the shaft be divided into seven parts, and let the top contraction be made six of them. In the column which shall be from thirty to forty feet, let the lowest diameter be divided into seven and a half parts; of these let the column 
have six and a half at the top as the amount of the contraction. Those which shall be from forty to fifty feet are also to be divided into eight parts, and these are to be contracted to seven at the top of the shaft under the capital. Further, if any are higher, let the contractions be determined proportionately in the same way. It is on account of the variation in height that these adjustments are added to the diameters to meet the glance of the eye as it rises. For the sight follows gracious contours; and unless we flatter its pleasure, by proportionate alterations of the modules (so that by adjustment there is added the amount to which it suffers illusion), an uncouth and ungracious aspect will be presented to the spectators [Vitruvius 1955, I: III.iii, 179, 181] (for the Latin text, see Appendix I).

Vitruvius begins his discussion of the diminution of the column shaft in the context of the arrangement of columns around a temple cella. Although in the text above it is not clear whether these observations about the diminution relate to all orders or only some of them, in Book IV iii on the Doric order he writes: "The column is to be diminished as directed for the Ionic order in the third book". ${ }^{13}$ Since for Vitruvius the shaft of the Corinthian column is the same as the Ionic one, it would seem that he saw these diminution ratios as applicable to the three orders. He relates the diminution to the adjustments made to the columnar orders in order to take account of optical effects.

Vitruvius distinguishes between different types of optical effect. He has previously been talking about the columns on the corners of a temple facade: "The angle columns also must be made thicker by the fiftieth part of their diameter, because they are cut into by the air and appear more slender to the spectators. Therefore what the eye cheats us of, must be made up by calculation." Here it is not distance that is considered as a cause for diminished appearance; the cause, as anyone who has looked at a column against the bright Mediterranean sky will attest, is the brilliance of the background creating glare and 'eating into' the volume of the column. ${ }^{14}$ The passage then goes on to stress that the variations in the contracturae - the term Vitruvius employs for diminutions-of columns are also due to an optical effect:

It is on account of the variation in height that these adjustments are added to the diameters to meet the glance of the eye as it rises. For the sight follows gracious contours; and unless we flatter its pleasure, by proportionate alterations of the modules (so that by adjustment there is added the amount to which it suffers illusion), an uncouth and ungracious aspect will be presented to the spectators.

Another translation renders the above passage thus:

These proportionate enlargements are made in the thickness of columns on account of the different heights to which the eye has to climb. For the eye is always looking for beauty, and if we do not gratify its desire for pleasure by a proportionate enlargement in these measures, and thus make a compensation for ocular deception, a clumsy and awkward appearance will be presented to the beholder [Vitruvius 1960: 84-86].

Vitruvius then goes on to talk about the rules governing the contracturae, and sets out the proportion of the top diameter relative to the bottom diameter of the shaft according 
to its height. A table expressing the variation in the contracturae according to column height, as described by Vitruvius, would look like this:

$\begin{array}{cc}\begin{array}{c}\text { Height of shaft } \\ \text { (feet) }\end{array} & \begin{array}{c}\text { Top to bottom diameter } \\ \text { ratio }\end{array} \\ \text { up to } 15 & 5 / 6 \\ \text { up to } 20 & (51 / 2) /(61 / 2) \\ \text { up to } 30 & 6 / 7 \\ \text { up to } 40 & (61 / 2) /(71 / 2) \\ \text { up to } 50 & 7 / 8\end{array}$

It can clearly be seen that in the left hand set of figures the shaft heights increase in multiples of ten, excepting the first figure, which is fifteen feet instead of the ten feet that might be expected. In the right hand column, the numbers in the numerator of the ratio are one unit less than the corresponding number in the denominator; both numbers in the numerator and the denominator increase by half a unit for every new column height in the left hand set of figures. Vitruvius gives no explanation as to why the shafts of columns should contract at all; Alberti, on the other hand, starts his discussion on the diminution precisely by giving such a reason: he found this reason in Nature.

\section{Alberti}

With each type of column the base, they felt, should have the same height, but different lineaments. Not only that: they should differ in the lineaments of almost all their parts, although on the whole the column should be similar. As we mentioned in the last book, the Ionians, Dorians and Corinthians all favoured the same lineaments for their columns. Their columns have a further similarity, in that, as in Nature, the top of the trunk is always made more slender than the bottom. Some maintained that the bottom should be one and a quarter times as thick as the top. Others, realising that objects appear smaller, the farther they are from the eye, sensibly decided that with a tall column the top should not be reduced as much as with a short column, and applied the following rules.

When a column is to be fifteen feet tall, the diameter at the base must be divided into sixths, five of which give the diameter at the top; but for columns between fifteen and twenty feet, they felt that the diameter at the top of the shaft should be eleven thirteenths that at the base; for columns of between twenty and thirty feet, the top is to be six sevenths of the base; then for those of up to forty feet, thirteen fifteenths; finally, for columns of up to fifty feet in height, the diameter at the top should be seven eighths that at the bottom. Thereafter, this same progression must be used to calculate how the width at the top increases, as the height of the column increases.

In these respects, then, all orders agree; although we have discovered, by measuring the works ourselves, that the Latins did not always follow these rules exactly [Alberti 1988, VII. vi: 201-202] (for the Latin text, see Appendix II). 


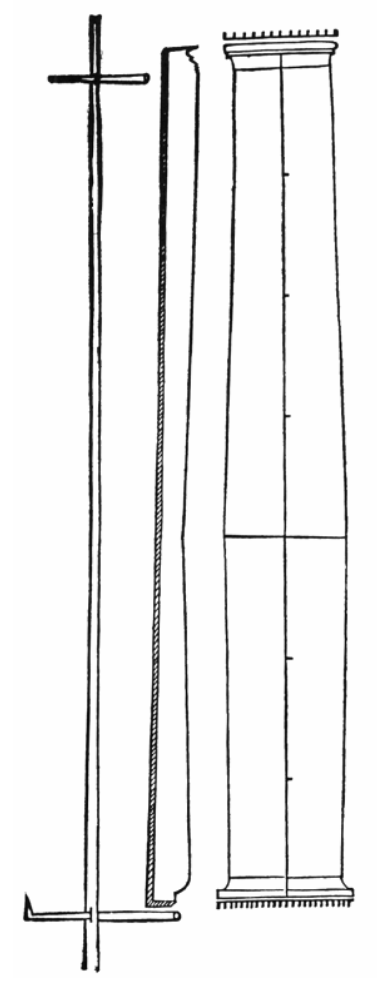

Fig. 2 (left). Cosimo Bartoli's 1550 illustration for the setting out of the shaft, according to Alberti [1988: VI.xiii, pp. 186-88]

The way Alberti sets out these rules varies slightly from that of Vitruvius. In terms of textual context, Alberti is discussing generalities and common aspects of the three columnar orders, Doric, Ionic, and Corinthian. ${ }^{15}$ His intention is to express what these orders have in common, and to justify these common characteristics in terms of an understanding of natural laws: "As we mentioned in the last book, the Ionians, Dorians and Corinthians all favoured the same lineaments for their columns. Their columns have a further similarity, in that, as in Nature, the top of the trunk is always made more slender than the bottom" [Alberti 1988: VII.vi, p. 201]. The diminution, then, is a common trait throughout the columnar orders, for as he concludes, "in these respects, then, all orders agree", and it is in relation to nature that they share this trait. Here the trunk must be understood as a botanical metaphor, and not an anthropomorphic one. ${ }^{16}$ Only after having expressed why it is natural for the column shaft to diminish does Alberti deal with the necessary adjustments in relation to the column height. The values are almost an exact transcription of the Vitruvian ones, although Alberti does not explicitly acknowledge his source here, and can be tabulated as follows: 
Height (feet) Top to bottom diameter ratio

$\begin{array}{cc}- & 4 / 5 \\ \text { up to } 15 & 5 / 6 \\ \text { up to } 20 & 11 / 13 \\ \text { up to } 30 & 6 / 7 \\ \text { up to } 40 & 13 / 15 \\ \text { up to } 50 & 7 / 8\end{array}$

First of all, Alberti introduces the 4/5 ratio which does not appear in De architectura, and which, according to him, some recommended, although he is silent about who these might have been and what reasons they might have had for this. Alberti also omits the column height that might correspond to this diminution ratio. Secondly, he avoids the use of non-integer numbers ${ }^{17}$ when setting out the ratios of top to bottom diameter, and substitutes the Vitruvian ratios for columns up to 20 and up to 40 feet by the equivalent fractions made up of the smallest possible integers, so that Vitruvius's 51/2 / 61/2 becomes Alberti's 11/13.

\section{Palladio}

The columns of each order must be shaped in such a way that the upper part is more slender than the lower and they have a swelling [gonfiezza] in the middle. In the case of diminution, one notices that the longer the columns are the less they diminish, as the height itself produces the effect of diminution from a distance; so if the column is up to fifteen feet high, divide the thickness [grosezza] at the bottom into six and a half parts, and the thickness at the top will be made of five and a half of these. If the column is between fifteen and twenty feet high, divide the lower thickness into seven parts, and the upper thickness will be six and a half; similarly, with those from twenty up to thirty feet high, divide the lower thickness into eight parts of which seven will be the thickness above; so those columns that are taller still should be diminished according to the method stated above, as Vitruvius teaches us in chapter 2 of Book III [Palladio 1997: I.xiii: 18].

$\begin{array}{ccc}\text { Column height (feet) } & \text { Diminution } & \text { Decimal equivalent } \\ \text { up to } 15 & 51 / 2 / 61 / 2 & =0.846153846 \\ 15 \text { to } 20 & 61 / 2 / 7 & =0.928571428 \\ \text { 20 to } 30 & 7 / 8 & =0.8750\end{array}$




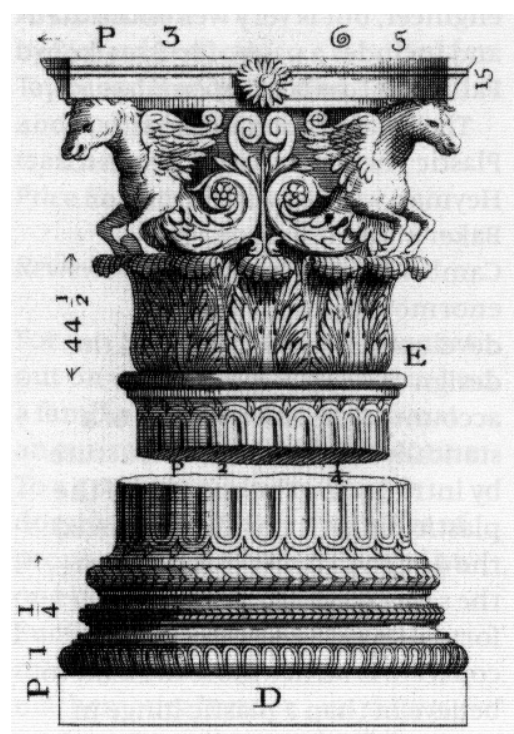

Fig. 3 (below). Column from the Temple of Mars The Avenger, according to Palladio

The translators note that Palladio really meant Vitruvius III.iii., but do not alert us to the differences from that text, and indeed, the sheer inaccuracy of Palladio's figures. To begin with, Palladio only provides proportions for three ranges of column height, rather than the five that Vitruvius and Alberti provide. From Palladio's text it should be possible to extend the series to calculate the diminution for columns from 30 to 40, from 40 to 50 feet, and so on. In fact, though, the resulting ratios do not form a regular progression. Taking $\mathrm{p} / \mathrm{P}$ to be the diminution ratio of columns up to fifteen feet, Palladio's series may be represented as:

$$
\mathrm{p} / \mathrm{P},(\mathrm{p}+1) /(\mathrm{P}+1 / 2),[(\mathrm{p}+1)+1 / 2] /[(\mathrm{P}+1 / 2)+1], \ldots
$$

which, extended for columns up to 50 feet high, gives:

$$
51 / 2 / 61 / 2,61 / 2 / 7,7 / 8,8 / 81 / 2,81 / 2 / 91 / 2,91 / 2 / 10, \ldots
$$

This cannot be a workable system because the diminution ratios alternately increase and decrease as the column height increases, in clear breach of Palladio's observation that "the longer the columns are the less they diminish". We find that what Palladio gives is but a jumble of the ratios Vitruvius recommends, and Alberti repeats, as can be seen from a comparison of Fig. 4 and Fig. 5. 


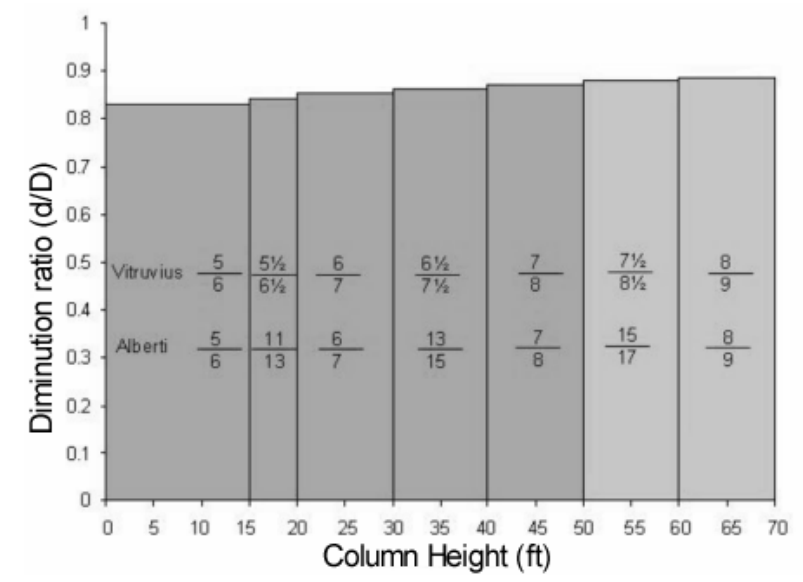

Fig. 4. The diminution ratios according to Vitruvius and Alberti



Fig. 5. The diminution ratios according to Palladio

If indeed Palladio believed he was giving the method according to Vitruvius, then the inaccuracy of the transcription raises the question as to how his figures come to be wrong. The error could be ascribed to a copyist, but the extent of the differences between the Vitruvian and Palladian versions seems too great for a translator's or a scribe's work to be the sole cause of the error. What does appear clear, though, is that Palladio cannot have had a copy of De architectura or De re aedificatoria open before him, unless it was a thoroughly corrupted one, while writing his passage.

\section{Form and Appearance}

Vitruvius seems to assume in the passage reproduced above, that the reader already understands that columns diminish, and sees no need for going into the reasons why they should do so. He therefore immediately goes on to describe how the diminution should 
vary according to the height of the column; someone unfamiliar with the subject could possibly read into the text that the very reason for the diminution is height itself.

Alberti on the other hand, makes clear that, irrespective of its height, a column must diminish in accordance with natural laws; that is, columns are more slender at the top in the same way that Nature shapes tree trunks. For Alberti, therefore, the diminution is an intrinsic characteristic of the column, the reason for which is entirely unrelated to any consideration of the viewer. It is only after having made this distinction between the reason for column diminution, and the reason for the sake of which columns of different heights should have different diminution ratios, that Alberti proceeds to give the table of diminution ratios that he adapted from Vitruvius.

In summary, therefore, it can be said that while for Vitruvius there existed a range of columns of different heights with different ratios of diminution, Alberti appears to be saying that there is a standard or original ratio of diminution, corresponding to a canonical or prototypical column, which is altered or adjusted to account for the observer's point of view. Alberti therefore makes a distinction between an aspect of the shape of the column (its taper) and the alterations and adjustments that have to be made to it on account of the changing viewing conditions resulting from the column's size [Vila Domini 1996].

This kind of distinction between what is permanently associated with a body and what is only temporarily or accidentally so is not a new one for Alberti to make. In his De pictura, he wrote that "mathematicians measure the form and appearance of things" 18 , and carried through this introductory distinction between form and appearance in his classification of the qualitates of a surface by saying:

Some of these properties are so much part of the surface that they cannot be removed or parted from it without the surface being changed. Others are ones which may present themselves to the eye in such a way that the surface appears to the beholder to have altered, when in fact the form of the surface remains unchanged. ${ }^{19}$

For Alberti, the permanent properties of the surface in relation to the art of painting are what he describes as the outline (ora or fimbria) and the 'face' (tamquam cutis), in other words, the actual construction of the surface itself, whilst the apparent ones depend on the viewing position, which changes the perceived shape of the outline, and on the lighting, which varies the way the face of the surface is seen in respect to colour, light and shadow. The permanent properties of the surface include what we would ordinarily call its shape, whilst the temporary ones would include its apparent shape. For example, a square piece of paper will always retain equal lengths for its sides whenever we choose to measure it, but will appear to have different shapes, presenting itself to us as a trapezium, a square, or a straight line, depending on our point of view.

Vincenzo Scamozzi's additions to the scenae frons of Palladio's Teatro Olimpico in Vicenza were meant to provide the urban setting of Sophocles's Oedipus Rex in the 
streets of ancient Thebes. In fact the views seen through the arches of the scenae were of elaborate three-dimensional constructions which reproduced the image of a city compressed in scale by the distortion of false perspective [Tavernor 1991: 103-105], in the tradition of Bramante's trompe l'oeil choir of Santa Maria presso S. Satiro.

\section{Diminution and Perspective}

This problem of the discrepancy between actual and apparent shape was at the centre of optical science and perspective. It is the task of the perspective method, that Alberti describes in De pictura, to establish a fixed relationship that will permit the representation of the permanent properties, in code, as it were, of surfaces as they appear when viewed from a particular position and under certain lighting conditions.

In order to explain Alberti's understanding of the implications of the diminution ratios given by Vitruvius, it is necessary to discuss in a little more detail some aspects of the fifteenth century invention of one-point perspective. In the perspective theory ${ }^{20}$ set down in Alberti's De pictura (1435) following Brunelleschi's (1377-1446) discovery and experiments [See Manetti 1927: 9; Manetti 1970], the key is to identify the field of vision as a flat, rectangular projection plane which intercepts the rays of vision that proceed from the objects to the eye, or vice versa. ${ }^{21}$ This theory is characterised by the single viewpoint of monocular vision, and employs the Euclidean principle of similar triangles. This method was probably arrived at in an artistic, building and surveying milieu, and, consequently, the projection plane takes on a very similar form to that of the surface of a painting or a window.

Alberti described in De pictura the method by which to create a perspective projection, referred to as the construzione legittima or the veil. One of the concerns of perspective theoreticians such as Alberti and Piero della Francesca (1410/20-92), was to show that, when projected onto the perspective veil, proportional relationships in real or imaginary space were 'translated', so to speak, into corresponding proportional relationships on the two-dimensional plane. These were derived from the spatial ones by a ratio determined by a constant rule. In architecture, such a proof would also reinforce the idea that the eye was able to read 'spatial mathematics' and, therefore, would be able to appreciate the harmonic proportions Quattrocento architects wished to employ.

In his article "Brunelleschi and Proportion in Perspective" [Wittkower 1978: 124136], Rudolf Wittkower clearly illuminates the geometrical and mathematical principles that were employed in order to explain this. Wittkower examines the development of the theory that was aimed to prove that dimensional relationships in space resulted in corresponding mathematical relationships when projected, through the perspective cone, onto a flat plane, such as the veil, a window, or a painting. The whole of this theory is based on the proportionality of similar triangles found in Euclid [Elements VI].

Some Renaissance perspective theoreticians endeavoured to find the rate by which objects diminish in perspective. Alberti did not give a rule regarding the ratios by which "a number of objects in space diminish for the eye of an observer" [Wittkower 1978: 
128] . In his De prospettiva pingendi, Piero della Francesca carried out a thorough investigation of the ratios of diminution in perspective (Fig. 6).

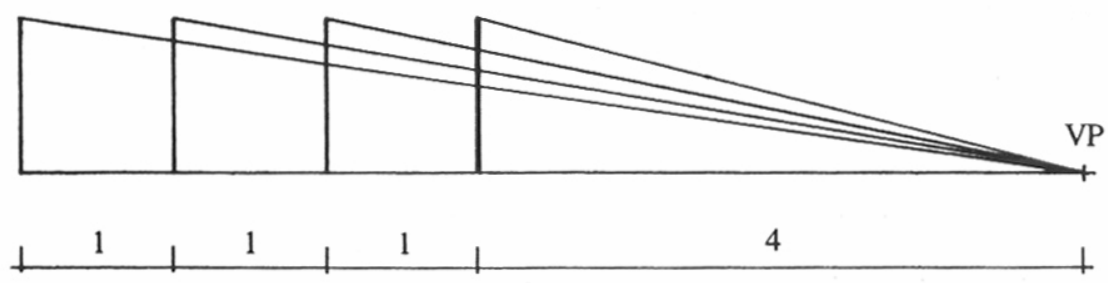

Fig. 6. Piero's model, showing the diminution of the apparent size of equal-sized and equallyspaced objects when represented upon the one-point perspective projection plane, or intersection. All objects and intervals between objects are 1 unit. The intersection in this example is at 4 units from the view-point $(\mathrm{VP})$. The size of the first object projected upon the intersection $(\mathrm{x})$ is found from the proportion 1 is to 5 , as $\mathrm{x}$ is to 4 , so that $\mathrm{x}=4 / 5$. Similarly, the size of the second object projected upon the first (y): 1 is to 6 , as $y$ is to $5 ; y=5 / 6$, and so on (adapted from Wittkower)

He worked on a model which considered a series of objects, of unit height, arranged in a row at unit intervals from the projection plane or intersection. The intersection was also a whole number of units away from the eye. Using the principle of similar triangles, he found by how much the first object would appear diminished on the projection plane, and expressed this as a ratio. Then, he calculated the diminution of the second object in relation to the first one, and then that of the third in relation to the second, and so on. If the distance from the eye to the intersection was four units, the ratio of the first object to its projection onto the intersection was $4 / 5$; that of the second object to the first $5 / 6$, and the third to the second 6/7. This would allow a painter to draw the height of an object in the row in relation to the drawn size of the previous one ${ }^{22}$, that is, the object one unit closer to the eye. The general series to which these ratios belong can be expressed in modern mathematical notation as $n /(n+1)$, and it starts at $1 / 2$ when the intersection is at one unit distance from the eye.

According to Wittkower, the particular case of this model that Leonardo 23 later examined must lead one to conclude that Brunelleschi and Alberti would have known ${ }^{24}$ about the method by which to calculate the ratios of objects receding in space. Piero's series can be written as:

$$
1 / 22 / 33 / 44 / 55 / 66 / 77 / 8 \text { 8/9... n/(n+1). }
$$

Because this series expresses the projected size of an object $n$ in terms of the projected size of object $n-1$, the actual values of the projected $\operatorname{sizes}^{25}$ are given by the following series:

$$
1 / 21 / 31 / 41 / 51 / 61 / 71 / 81 / 9 \ldots 1 / n
$$

Mathematically, this series tends to zero as the distance of the object from the eye approaches infinity. This means, of course, that the projection on the intersection 
becomes smaller and smaller the further the object is from the eye, though it decreases at a smaller and smaller rate also. Returning now to the diminution ratios recommended by Vitruvius and Alberti, it is possible to rationalise the expression of the ratios so as to write a table equivalent to the two above as follows:

$\begin{array}{rc}\text { Height (feet) } & \text { Top to bottom diameter ratio } \\ \text { up to } 15 & 10 / 12 \\ \text { up to } 20 & 11 / 13 \\ \text { up to } 30 & 12 / 14 \\ \text { up to } 40 & 13 / 15 \\ \text { up to } 50 & 14 / 16\end{array}$

It can now be seen that the ratios in the right hand column belong to the generic series that in modern mathematical notation can be expressed as $n /(n+2)$, starting at $n=10$; I $n=1$ shall from now on refer to the following series as the 'modified' Vitruvian series:

\begin{tabular}{lllllllllllllll}
$n=1$ & \multicolumn{1}{c}{$n=10$} & & & & $n=14$ \\
$1 / 3$ & $2 / 4$ & $3 / 5$ & $4 / 6$ & $5 / 7$ & $6 / 8$ & $7 / 9$ & $8 / 10$ & $9 / 11$ & $10 / 12$ & $11 / 13$ & $12 / 14$ & $13 / 15$ & $14 / 16$ & $\ldots$
\end{tabular}

The value of the terms in this series $n /(n+2)$ tends to 1 as $n$ approaches infinity. This implies that, the taller the column, the closer the width of the top diameter approximates the width of the bottom one, so that the column shaft approximates the shape of a cylinder. ${ }^{26}$ So, in some sense, the series expressing the size of receding objects onto the projection plane is opposite to the modified Vitruvian series above, for as the distance increases in the perspective series, the size of the projection decreases, whilst in the modified Vitruvian series the size of the top diameter increases with height, or increased distance from the eye.

The question then arises as to whether there might be a connection between the Vitruvian series and those of Leonardo and Piero. This question is especially tantalising since the modified Vitruvian series responds to some sort of optical correction, the precise nature of which is unclear, and the Leonardo and Piero series set out the very basics of a means for representing optical effects on a plane, one-point perspective. These apparent similarities need careful analysis, for number series had been used for centuries and for many different purposes. The fact that two series should appear similar does not necessarily imply that the subjects to which they are each connected are themselves related. But in this case, it is possible to interpret the situation as a relationship of inversion taking place. The Piero series, $n /(n+1)$, is almost the same as the modified Vitruvian series, $n /(n+2)$, but the two are designed to account for opposite effects. The perspectival series describes the appearance of real objects, that is, the decreasing size of their projection onto the plane, while the columnar series accounts for a correction of the 
object itself so that it will appear in a certain way on the plane (if we understand what we see as being projected onto an invisible plane) by altering the very objects that are projected; the latter works backwards, from the conjectural projection plane onto the object, rather than from the object onto the plane.

Antique painting had achieved considerable naturalistic realism even in the representation of complex geometrical spaces such as are found on surviving Roman wall paintings at Pompeii and Herculaneum. Despite the clear evidence in some of these murals of the use of construction points very similar to Alberti's punto centrico, it is as yet uncertain whether a consistent theory of perspective representation as that developed in the Renaissance was also available to ancient artists. In particular, there are no surviving examples of paintings or texts that may unambiguously prove the existence of such a theoretical knowledge, even if the words of Vitruvius are cited by those defending the idea of antique perspective. Vitruvius invokes the science of optics in calculating the adjustments to be made to architectural elements, and in the scenographia, a term referring to the scenae frons and which is at times equated with perspective because it faithfully represented a view of buildings. But this representation need not necessarily be equivalent to the Renaissance technique of spatially consistent perspective, despite the fact, or perhaps even because of it, that antiquity was well aware of Euclid's third century B.C. treatises on geometry and optics (see, for example, [White 1956]).

One of the traits of the Renaissance perspective method of projection is that the size of objects depends on the distance between the plane of the intersection and the parallel plane that the object exists in; in other words, an object will appear smaller on the intersection when its perpendicular distance from the projection plane increases. This means that an object may actually be further away from the view-point than another of the same real size, say because the second object is directly in front of the view-point whilst the first is further to the right, but will appear represented as of equal size on the intersection if they happen to be on the same plane parallel to the projection plane. Onepoint perspective involves no convergence of any lines parallel with the picture or projection plane-vertical, horizontal or otherwise. It is only lines that are not contained by a plane parallel with the projection plane that converge towards a vanishing point, and therefore reflect the decrease in size due to distance. This is the case with the representation of the column (Fig. 7, Fig. 8, Fig. 9): for example, if a column were perfectly cylindrical, the top of the column would appear of the same size as the bottom, and so the column's profile would appear on the projection plane as two parallel, vertical lines, whereas it is clear that the upper part of the column is actually further away from the view-point than the section of the column on the same level as the horizon, and would therefore be seen as more slender. This effect of the Renaissance perspective projection method gave rise to several problems ${ }^{27}$, such as edge distortion; but the most important consequence of their method regarding the subject of this paper is that Renaissance artists and perspective theoreticians would have been entirely unable to detect, through the means of one-point perspective, the proper reduction in size that 
distance not accrued by extension into the picture plane but, rather, along planes parallel to its surface, was inevitably bound to produce under any real viewing conditions.

As Alberti points out in the introductory remarks to the diminution series, "objects appear smaller, the farther they are from the eye, [so the ancients] sensibly [consultissime] decided that with a tall column the top should not be reduced as much as with a short column." Therefore, although it is clear that Alberti realised that objects that are far from the eye decrease in apparent size, whether it be due to height or horizontal distance, it was not through one-point perspective that he could have studied the effect of column height on the visual perception of the column.

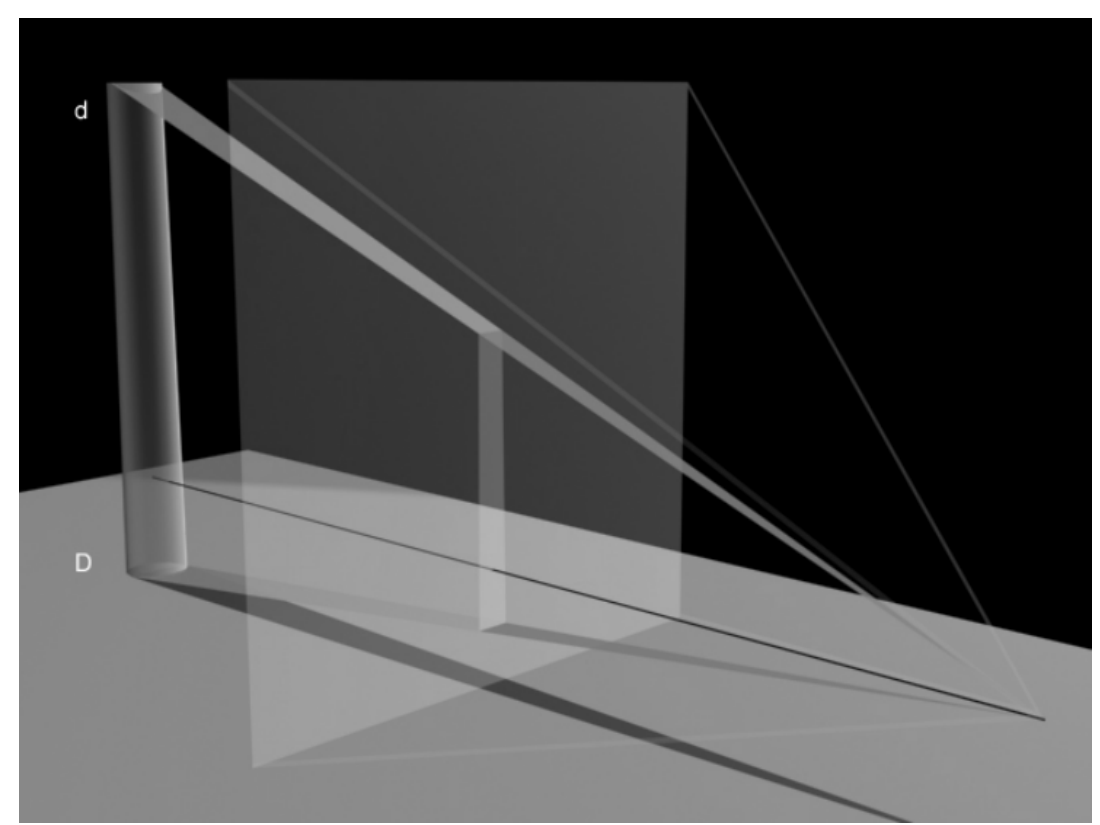

Fig. 7. The perspectival model of representation applied to the view of a column shaft 


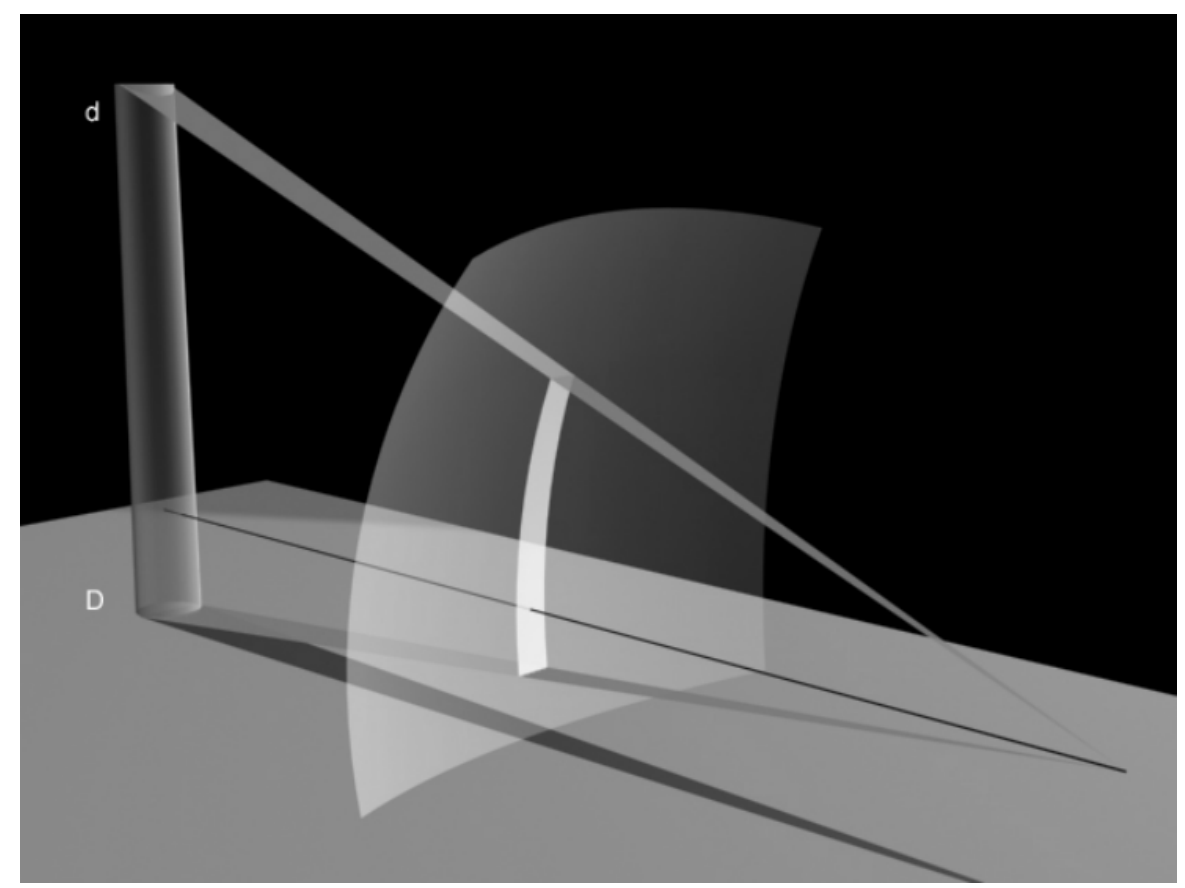

Fig. 8. The optical model of representation applied to the view of a column shaft

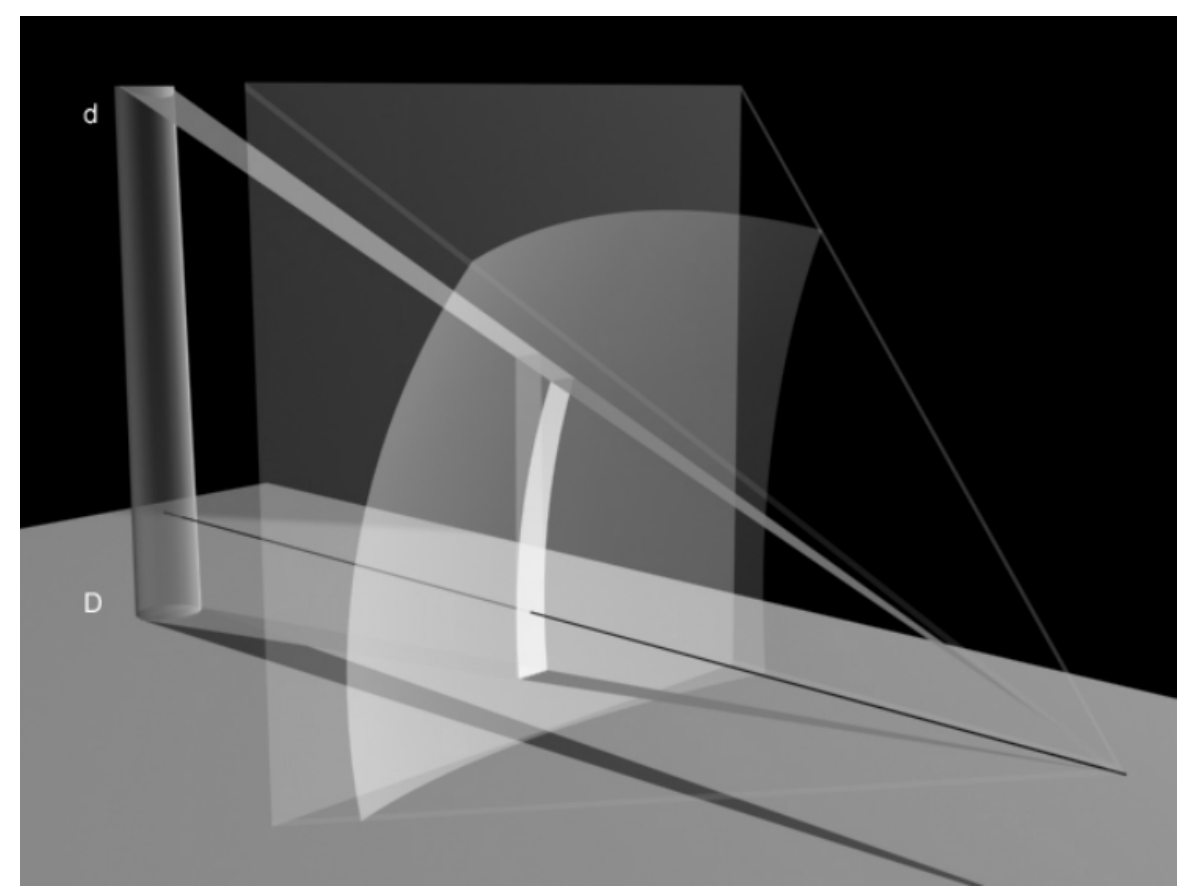

Fig. 9. The optical and perspectival models of representation applied to the view of a column shaft 


\section{Practice}

A question one inevitably comes to in relation to this subject is what may have been the practice of architects of the different periods under discussion. What did those tasked with putting up buildings in Classical Greece, Rome, and the Renaissance actually do as regards the column diminution? The answer to this must rely on extensive and accurate survey information of the kind which is unfortunately hard to come by in widely available publications. The difficulties of arriving at accurate survey measurements of ancient Greek columns are compounded by the fact that they would originally have been covered by a layer of stucco, now mostly disappeared. Recent detailed examination of Roman architectural elements, on the other hand, would appear to suggest that the diminution in these examples was not as pronounced as described in the Vitruvian series.

Another question one may ask is whether the diminution series was devised with a particular order in mind. This may well have been the case, but if so, the numbers themselves offer little to uncover which particular order it may have been. In fact, because the diminution values are expressed as ratios, we find that it is impossible to tell whether they relate to slender or sturdy columns, and therefore making it impossible on this basis alone to determine whether they may relate to Doric or Ionic (and Corinthian) type shafts. Curiously, because the dimension of the upper diameter of the shaft is given as a proportion of the lower diameter, if a thicker column-i.e., one with a larger width to height ratio-were designed using the Vitruvian diminution ratios, it would have a shaft whose outline is more prominently inclined than that of a slender column. This peculiarity responds pretty closely to the reality of the outlines of Ancient Greek Doric examples when compared with Ionic, or Hellenistic and Roman Corinthian, where these last ones are composed of straighter shafts. In other words, the Vitruvian diminution ratios would initially seem equally well suited to describe a shaft belonging to any order.

Better access to the reality of Renaissance buildings ought to make obtaining detailed survey information easier, although the measurement of the upper diameter necessary to establish the diminution is not one of the most usual ones taken. As well as the buildings and the texts, the Renaissance has left a wealth of drawn material from which in principle it ought to be possible to extract some information regarding the diminution of columns. The reality is that the type of engraving furnished in Palladio's treatise, for example, is difficult to interpret with much accuracy, though tentative studies I have made tend to suggest columns less diminished than the recommended by the Vitruvian series.

Alberti produced no drawings in his ten books, and one might have to rely on the text for information as to his view on the diminution because most of his built works were executed by others who had an uncertain degree of independence from Alberti himself. In fact, if Alberti intends architects to adjust the diminution to the height of the column, and does not recommend the ratios he copies from Vitruvius, then there is no way of knowing from his treatise what he intended his contemporaries and followers to do. When Alberti, a little later on in the Ten Books, comes to describe in detail the setting out of a column shaft, he does not follow the series he transcribed from Vitruvius, but 
decreases the amount of the diminution considerably by using different ratios. In VI.xiii, he says: "according to the size of column (a subject to be debated in the appropriate place) the length of the diameter of the top circle is derived from that of the lowest circle...". ${ }^{28}$ The appropriate place is either VII.vi, where he gives the aforementioned series, or, a little below, where he describes a thirty foot high column: "The maximum overall diameter is divided into nine equal parts, of which the diameter of the projection at the top takes up eight, giving it the ratio nine to eight, called the sesquioctave". 29

Now, this 8/9 ratio would correspond, by an extension of the Vitruvian and Albertian series, not to a thirty foot column, but to a column of a height up to seventy feet-in the series they both give, columns of up to thirty feet should be constructed with the ratio 6/7. Applied as it is by Alberti, to a thirty foot column, it gives a smaller diminution than if he had followed the diminution series. This smaller diminution (ratio) is very possibly consistent with the Roman examples he claims to have measured. Alberti was probably not an exception in reducing the amount by which the shafts were diminished; the Spanish eighteenth-century translator of Vitruvius, Ortiz y Sanz, was of the opinion that greatly diminished columns, such as those recommended by Vitruvius, were ungainly to look at. ${ }^{30}$ But what is puzzling is that in his treatise Alberti should have set down the diminution series and then this example which ignores it, almost side by side, without telling us the reason for disregarding the former and adopting the latter.

Columns were certainly diminished in Palladio's time, and indeed in Palladio's own work, but the fact that he gave such a jumbled version of the diminution ratios in itself may shed some light on his personal view on how the diminution was worked out in practice. If Palladio used the Vitruvian diminution method in the designs of his own buildings, it would seem reasonable to expect him to have a better recollection of the figures involved when he came to set them down in the Quattro Libri; or at least his reliance on them for his own practice as an architect would have compelled him to check the accuracy of the figures he was handing down in writing. This, however, he cannot have done; and what is more, because he made the mistake of ascribing to columns of 20 to 30 feet in height a diminution greater, rather than smaller, than that of columns from 15 to 20 feet high, it seems that he was not aware of the effects of the ratios he was providing. This appears all the stranger since Daniele Barbaro's edition of Vitruvius on which Palladio collaborated, correctly gives the ratios of the Latin source (Book III, chapter 2 of this edition).

\section{Further Questions}

Because we are familiar with Vitruvius's fondness for Greek terminology and methods already outdated in his own time we may not be surprised that he should have set down a method for calculating the diminution of columns that, according to Alberti at least, architects contemporary with Vitruvius seemed not to employ. But this leaves us without an explanation as to the origin of the diminution series, and it is possible also that Vitruvius himself did not know. He might have known of it through a document now lost, possibly of Greek or Hellenistic origin, ${ }^{31}$ but it is possible that he may not have 
understood its precise effect on the visual appearance of the column, or the exact process by which it was obtained.

As we have seen, the method originally employed to calculate the ratios given by Vitruvius in the diminution series cannot have been the one which was used by Alberti and his contemporaries to construct perspective projections. Indeed, this type of perspective could not register any change in size due to increased distances from the viewing point, if these increases were due solely to height. Therefore, it is necessary to conclude that a different method was used in antiquity in order to arrive at these ratios. This method is likely to have been derived from the science of optics, on which Euclid was an authority, or from some application of it, perhaps following Richard Tobin's suggestions $s^{32}$ of the possible development of a system of perspective projection based on a spherical projection plane. Any such method would have made it possible to detect increases in distance due to height, and the consequent apparent reductions in the size of objects. A further, perhaps simpler, method would be one reliant exclusively on the ratios of distances from the viewing point to the top and bottom of the column, for, with a previously established viewing position, it would be a relatively easy task to calculate arithmetically and graphically the proportionate reduction in size of the top diameter, and adjust it so as to achieve a measurable perceptual ratio with the bottom diameter.

The actual method employed in antiquity would be dependent on an elusive 'correct' or desirable way of, or attitude towards viewing a facade composed of columns. The existence of a precise method for adjusting the appearance of the columns' top diameter must have responded to a particular appearance that was sought, or to a particular effect that was to be avoided. One would be inclined to think from the remark "what the eye cheats us of, must be made up by calculation", that this desired or undesired appearance was itself subject of being measured.

In order to understand the ratios it would appear necessary, therefore, to develop a model of viewing a building which may have applied in antiquity. I would suggest that a starting point for such future investigation in regard to the diminution of columns should be to determine what optical effects the Vitruvian diminution ratios actually have on the perceived ratios of top to bottom diameter when employed to govern the proportion of columns.

Furthermore, another question that arises regarding the diminution, is what might have been Alberti's and Palladio's intentions in providing this information, and, particularly, whether they intended architects to use these tables or not. Alberti subscribes to the view that architecture, having originated in Asia and acquired beauty in Greece, was finally perfected by the Romans. ${ }^{33}$ As it is quite clear to him, from his own surveys, that the kind of diminution recommended by Vitruvius was not in use amongst the Romans, he can only have regarded this as an example of Vitruvius's Grecophilia. But unfortunately, in this passage on the diminution Alberti does not give what rule, if any, the Romans did employ. 
The diminution series is not the only example of optical adjustments given by Vitruvius and Alberti. Amongst other optical adjustments, their recommendations regarding the height, or thickness of the $\operatorname{architrave}^{34}$ in relation to column height constitute a very similar case to that of the column diminution. The essence of the matter is the same, that is, the higher the column, the thicker the architrave is required to be in relation to the column diameter (and height), in order to compensate for the reduction of perceived size due to the increased distance (height) from the eye at which the architrave is positioned. I will not enter into a detailed examination of this, but it can readily be seen from the recommended ratios that the situation is much the same as with the column diminution, and most of the questions that apply to one are, therefore, also relevant to the other.

To conclude, then, we have seen that the original source of the diminution ratios might have been known to Vitruvius. But whether he, Alberti or Palladio understood the method by which these ratios were derived, or their precise effect on the visual appearance of columns, is something that must remain questionable. At the same time, I have pointed to the need for more research to be carried out in relation to ascertaining the optical effects of using the diminution ratios. Any such research should probably begin by examining the mathematical nature and characteristics of the figures involved, and the optical effects when viewing columns designed using these ratios.

\section{Appendix I : Vitruvius on the Diminution of the Column Shaft}

Etiamque angulares columnae crassiores faciendae sunt ex suo diametro quinquagesima parte, quod eae ab aere circumciduntur et graciliores videntur esse aspicientibus. Ergo quod oculus fallit, ratiocinatione est exequendum. Contracturae autem in summis columnarum hypotracheliis ita faciendae videntur, uti, si columna sit ab minimo ad pedes quinos denos, ima crassitudo dividatur in partes sex et earum partium quinque summa constituatur. Item quae erit ab quindecim pedibus ad pedes viginti, scapus imus in partes sex et semissem dividatur, earumque partium quinque et semisse superior crassitudo columnae fiat. Item quae erunt a pedibus viginti ad pedes triginta, scapus imus dividatur in partes septem, earumque sex summa contractura perficiatur. Quae autem ab triginta pedibus ad quadraginta alta erit, ima dividatur in partes septem et dimidiam; ex his sex et dimidiam in summo habeat contracturae rationem. Quae erunt ab quadraginta pedibus ad quinquaginta, item dividendae sunt in octo partes, et earum septem in summo scapo sub capitulo contrahantur. Item si quae altiores erunt, eadem ratione pro rata constituantur contracturae. Haec autem propter altitudinis intervallum scandentis oculi species adiciuntur crassitudinibus temperaturae. Venustates enim persequitur visus, cuius si non blandimur voluptati proportione et modulorum adiectionibus, uti quod fallitur temperatione adaugeatur, vastus et invenustus conspicientibus remittetur aspectus. [Vitruvius 1955, I: 178-180].

\section{Appendix II : Alberti on the Diminution of the Column Shaft}

His omnibus columnis bases altitudine coaequales inter se, sed lineamentis varias substituendas putarunt. Quid plura? Totis fere lineamentis partium inter se dissimiles 
fuere; in columnarum tamen ratione multa ex parte convenerunt. Nam columnae lineamenta, de quibus superiore diximos libro, cum Ionici tum et Corinthii tum et Dorici probavere; et in hoc etiam convenerunt, imitati naturam, ut truncos quidem columnarum in summo nunquam non graciliores habendos ducerent quam in imo. Fuere que dixerint crassiores in imo ponendas ex quarta quam in summo; alii, quod intelligerent prospectas res eo minores videri, quo [uno] ab oculo semotiores sint, consultissime idcirco praelongas columnas minus habendas graciles putarunt in summo, quam quae essent breves; atque de his ita constituerunt:

imam columnae crassitudinem, ubi ea quidem ad pedem usque quindenum futura longa sit, dividendam esse in partes sex, atque ex his una parte abiecta, reliquas quinque dandas supremae crassitudini. Columnam autem a quindeno ad pedes usque viginti ita esse comparandam putarunt, ut ex tribus atque decem partibus imi scapi summo relinquerentur; a vigesimo autem ad pedem usque trigesimum columnas imo habendas $V I I$, summo sex; inde ad pedes $X L$ ex $X V$ imae columnae partibus tris atque decem in summo relinquendas, duas reliquas abigendas; demum ad pedes usque $L$ columnam quidem ad basim fore oportere crassam VIII, ad altum vero VII. Ea deductione deinceps ratiocinandum, ut quo altius columnae caput sit, eo et crassius relinquatur.

Itaque in his universae convenere. Sed nos ex operum dimensionibus ista haec apud nostros Latinos non penitus fuisse observata comperimus. [Alberti 1966, II: 567-569].

\section{Notes}

1. Some of the material in this paper has previously appeared in the author's "The Diminution of the Column in Alberti and Vitruvius; Concerning Optical Corrections" [Vila Domini 1996] and "Column Marginalia" [Vila Domini 2000].

2. "For I grieved that so many works of such brilliant writers had been destroyed by the hostility of time and of man, and that almost the sole survivor from this vast shipwreck is Vitruvius, and author of unquestionable experience, though one whose writings have been so corrupted by time that there are many ommissions and many shortcomings. What he handed down was in any case not refined, and his speech such that the Latins might think that he wanted to appear Greek, while the Greeks would think that he babbled Latin. However, his very text is evidence that he wrote neither Latin nor Greek, so that as far as we are concerned he might just as well not have written at all, rather than write something that we cannot understand" [Alberti 1988: VI, i, p. 154].

3. "I have told you that I desire to make my language Latin, and as clear as possible, so as to be easily understood. Words must therefore be invented, when those in current use are inadequate; it will be best to draw them from familiar things. We Tuscans call a fillet the narrow band with which maidens bind and dress their hair; and so, if we may, let us call 'fillet' the flat band that encircles the ends of the column like a hoop. But the ring positioned at the top nest to the fillet, which binds the top of the shaft like a twisted cord, let us call 'collar"' [Alberti 1988: VI, xiii, p. 186].

4. The words used by Alberti and Vitruvius to refer to these is not 'orders', but others such as formas, or simply columnas.

5. Referring to his description of the column shaft, Alberti writes that it "is not a discovery by the ancients, handed down in some writing, but what we have noted ourselves, by careful 
and studious observation of the works of the best architects" [Alberti 1988: VI, xiii, p. 188].

6. See Alberti De re aedificatoria VII x, and Vitruvius De architectura IV iii, III iii. These passages set out the rules for dividing up the length of a temple facade into modules according to the columnar style (Doric or Ionic) and the number of columns in the portico $(4,6$, and 8$)$. The module for the Doric is equivalent to half a column diameter, whereas in the Ionic it is a whole column diameter. The information provided by Vitruvius is correct, although the number of modules into which to divide the Doric octastyle portico is omitted. Alberti provides this information, but gives 56 which is incorrect, as is the 41 he gives for the Doric hexastyle. Bartoli's drawings show the correct number of modules for these two porticoes, 57, and 42 (as Vitruvius), respectively. The recent English translation of De re aedificatroria [Alberti 1988] gives 11 for the Ionic tetrastyle, where Vitruvius, Bartoli's illustration, and other editions of Alberti's text give the correct $11 \frac{1}{1 / 2}$.

7. For Alberti, the only difference between the Corinthian and the Composite (which he refers to as Italian) columnar styles is the make-up of the capital; Alberti rejects other types of column style in De re aedificatoria VII vi and VII viii, (Cf. Vitruvius De architectura IV i) but creates his own variations which are not described in his treatise, such as those on the facade of the Tempio Malatestiano.

8. Those who claim that Alberti sets out the five columnar styles are mistaken. For example, Peter Murray writes: "Alberti gives the first consistent theory of the use of the five orders since classical times" [Murray 1986: 53]. In De re aedificatoria VII vi, Alberti talks about three main types of capital, the Doric, Ionic, and Corinthian, and he adds the Italian capital as a variant worthy of inclusion because of its beauty. Although he claims that the Doric was used in ancient Etruria, perhaps before the Greeks used it, he does not identify a separate Tuscan capital. Rather, for Alberti, the Tuscan and the Doric seem to be one and the same thing. When describing a monumental column in De re aedificatoria VIII iii, Alberti comes close to Vitruvius's Tuscan column, but calls it Doric.

9. For Alberti, the Doric column has a base, and so all columns consist of the three elements: base, shaft and capital.

10. Both Alberti and Vitruvius refer to the column shaft and to the whole column including base and capital with one word, columna, which makes it difficult on occasions to be sure whether the measurements or proportions they describe relate to the whole element or only to the shaft.

11. "DIMINUTION-The amount of tapering or reduction in the diameter of a column shaft from bottom to top, generally two-ninths to one-fifth of the lower diameter in Doric and one-sixth to one-seventh of the lower diameter in Ionic and Corinthian columns" [Dinsmoor 1950: p. 390]. It should be noted here that Dinsmoor expresses the diminution as the difference in width between the top and bottom diameters, whereas Vitruvius, Alberti and Palladio express it as the ratio of top to bottom diameters. Dinsmoor's values for the diminution correspond to ratios of between $7 / 9$ (31/2/ 41/2) and 4/5 for Doric columns, and between 5/6 and 6/7 for Ionic and Corinthian columns. Note that when I refer to a smaller diminution, I mean that the amount by which the top diameter diminishes is less, and consequently the ratio of top to bottom diameter is greater; so a column with $5 / 6$ diminution ratio has a greater diminution than one with a $6 / 7$ ratio, though this latter ratio is obviously greater than $5 / 6$.

12. Vitruvius appended an illustration exemplifying the method by which to draw the entasis, but this had been lost by the time Alberti read him. (De adiectione, quae adicitur in mediis 
columnis, quae apud Graecos entasis apellatur, in extremo libro erit formata ratio eius, quemadmodum mollis et conveniens efficiatur, subscripta [De architectura III iii]). The shaft that Alberti describes never actually swells out, but rises verticallly upwards from the bottom projection up to a height of three sevenths of the shaft, and then, in another straight line, proceeds to meet the underside of the top projection. This seems a rather crude simplification of the complex and delicate curves favoured by the Greeks, which Vitruvius would have probably endorsed. Alberti was by no means alone in advocating columns without entasis; in the eighteenth century, Ortiz y Sanz wrote with reference to Vitruvius's lost drawing of the entasis: Deseo que mis Archîtectos Españoles no usen de tales colunas con éntasis o barrigudas, y nunca culparé á ninguno que ignore el modo de hacerlas. Omito, por tanto, la figura, como trabajo perdido, y aun perjudicial, y quisiera que la omitieran todos los escritores de Archîtectura [Vitruvius 1987: 68, fn. 23].

13. Contrahatur columna ita, uti in tertio libro de ionicis est scriptum [Vitruvius 1955: IV iii, pp. 220-221].

14. Vitruvius then goes on to say that it is the eye that cheats us of the apparently missing parts of the column, and this may seem a little at odds with the fact that it is the air that is bright and creats the glare; but at that time-and indeed in Alberti's — it was not clear whether light rays emanated from the eye of from the objects seen.

15. Cf. notes 8 and 9 above.

16. Truncus in Latin means indiscriminately tree trunk, human torso, or column shaft. At the beginning of Book III, Vitruvius insists on the derivation of the dimensions of temples from the measurements of the human body in order that design should follow the methods of Nature. Alberti links the diminution of the column shaft to the shape of certain natural forms, and we may be excused for initially preferring the human torso to the tree trunk as a model on which to base the column shaft, especially bearing in mind that, later on in the text, Alberti describes the evolution of column proportions from an anthropomorphic origin [Alberti 1988: IX.vii]. However, this association proves to be a tricky one. In De statua, Alberti provides tables recording the average proportions of man taken from a selection of living samples "considered the most beautiful by those who know" (...quae apud peritos pulcherrime haberentur...) [Alberti 1972: De statua 11, 134135]. In these Tabulae dimensionum hominis the top of the human torso is given as wider than its lower part, making it difficult to associate the idea of a slender top with the human torso. Rather, the metaphor must relate in this case to the trunks of trees. The following extract from the Tabulae... shows that the human trunk is not more slender at the top:

$\begin{array}{lccc}\text { Maxima prominentia inter articulos ischiae } & \text { feet } & \text { degrees } & \text { minutes } \\ \begin{array}{l}\text { (maximum width between hip joints) } \\ \begin{array}{l}\text { Maxima latitudo inter ambo latera supra } \\ \text { ischiam }\end{array}\end{array} & 1 & 1 & 0 \\ \begin{array}{l}\text { (maximum width between sides above hips) } \\ \text { Maxima amplitudo in pectore sub asellis } \\ \text { (maximum width of chest beneath armpits) }\end{array} & 1 & 1 & 5 \\ \begin{array}{l}\text { Maxima latitudo inter angulos scapularum } \\ \text { (maximum width between point of }\end{array} & 1 & 5 & 0 \\ \text { shoulders) } & & & 5\end{array}$

[Alberti 1972: 136-137]. 
17. On the Renaissance preference for whole numbers see "The Changing Concept of Proportion" [Wittkower 1978: 109-123, esp. 111-116].

18. Illi [...] species et formas rerum metiuntur [Alberti 1972: De pictura I.i, 36-37]. Grayson translates species et formas as "shapes and forms", but in view of the subject and of Alberti's following classification of the properties of the surface into those which do not alter and those that do, depending on viewing position and lighting conditions, it seems to me to be preferable to translate species as appearance, meaning apparent form, as opposed to actual form of the surface. This meaning of species is also the first sense in which it is normally used in ancient sources, and the closest to its etymological meaning. For a more complete discussion of this term, see [Pollit 1974: 436-439].

19. Qualitatum aliae ita superficiei inhaerent ut prorsus nisi alterata superficie minime semoveri aut seiungi queant. Aliae vero qualitates huismodi sunt, ut eadem facie superficiei manente, ita sub aspectu tamen iaceant, ut superficies visentibus alterata esse videatur [Alberti 1972: De pictura I.ii, p. 36].

20. For a good introduction to perspective see [Kemp 1990], especially Chapter I.

21. On rays of light proceeding from the object or the eye, see note 14 above.

22. It also allowed him to calculate the ratio of any object in relation to the size of the intersection. For this, he simply multiplied the individual ratios, so that in the example, the size of the second object on the intersection is given by multiplying the ratio of the first object to the intersection with the ratio of the second object to the first: $(4 / 5) \times(5 / 6)$ $=4 / 6$. The size of the third object on the intersection would be: $(4 / 5) \times(5 / 6) \times(6 / 7)=$ $4 / 7$, and so on.

23. Leonardo da Vinci simplified the problem of the perspectival diminution of objects by considering a particular case of Piero's model, in which he made the first object coincident with the projection plane, and at one unit distance from the eye. This model allows us to express the size of the projection of object $n$ relative to its real size as $1 / n$, where $n$ is also the number of units by which the object is away from the eye, the distance from the eye. Thus, in this model, the apparent, projected size of object $n$ is inversely proportional to its distance from the eye.

24. "One must take it for granted that artists had known about the simple proportion [...] ever since similar triangles had been used in the context of perspective, and from this one is bound to infer that Leonardo's progression can never have been a secret" [Wittkower 1978: 132].

25. See note 22 above.

26. The series is equivalent to the one that can be drawn from the table given by Vitruvius, except that both the numerator and denominator are doubled. The series arising from Vitruvius's table is $(n / 2) /[(n / 2)+1]$.

27. The angle of vision had to be kept below a certain limit if the objects and spaces at the edges of the painting - or at points on the painting distant from a central vanishing point-were not to appear uncomfortably distorted (for a concise discussion of this problem in relation to a row of columns, see [Gombrich 1972: 215-216]). But, in turn, small angles of vision would often mean longer viewing distances, which would have been laborious to construct in practice. Artists were aware of these undesirable effects and endeavoured to compensate unsightly distortions in a number of ways, such as limiting the angle of vision.

28. In [Alberti 1988: VI.xiii, p. 188], the translation of diametro imae plantae as "from the diameter of the bottom recess" is incorrect; it means "from the bottom diameter". 
29. [Alberti 1988: Book VII.vi, pp. 201-202]. Sesquioctave means another eighth.

30. Si aun despues de la doctrina Vitruviana en orden á la diminucion de las colunas me es lícito decir mi parecer, aconsejo á los Archîtectos, que en sus colunas hagan todavia menos diminucion que las que prescribe Vitruvio, pues las colunas muy disminuidas, como la Toscana, hacen muy mala vista [Vitruvius 1987: 68, n. 22].

31. Hermogenes was one of the sources cited by Vitruvius, De architectura III.iii.

32. [Tobin 1990]. In this article, Tobin analyses possible misreadings of Theorem 8 in Euclid's Optics, and reconstructs a hypothetical spherical projection method that the Greeks might have been able to develop following Euclidean geometry and optics.

33. "Building, so far as we can tell from ancient monuments, enjoyed her first gush of youth, as it were, in Asia, flowered in Greece, and later reached her glorious maturity in Italy" [Alberti 1988: VI.iii, p. 157].

34. "They therefore laid down the following rules: for columns up to twenty feet, the height of the beam should be one thirteenth that of the column; for those up to twenty-five feet, a twelfth; then, for columns up of to thirty feet, the beam should be one eleventh of that height; this same progression was then used to calculate the remainder" [Alberti 1988: VII ix]. Cf. [Vitruvius 1955: III.v]: "The proportion of the architraves should be as follows: if the columns are from twelve to fifteen feet, the height of the architrave should be half the thickness of the column at the bottom; from fifteen to twenty feet let the height of the column be divided into thirteen parts, and the height of the architrave be one part; from twenty to twenty-five feet, let the height be divided into twelve parts and a half, and let the architrave be one part of that in height; also from twenty-five to thirty let it be divided into twelve parts, and let the height be made of one part. Thus the heights of the architraves are to be determined in accordance with the height of the columns."

Alberti

Column height (feet)

Height of beam

Up to 20
Up to 25
Up to 30

$\begin{array}{ccc}\begin{array}{c}\text { Column height } \\ \text { (feet) }\end{array} & \begin{array}{c}\text { Vitruvius } \\ \text { Height of } \\ \text { architrave }\end{array} \\ 15-20 & \mathrm{D} / 2 & \begin{array}{c}(0.5 \text { of } \\ \mathrm{D})\end{array} \\ 20-25 & 1 / 13 & 2 / 26 \\ 20-25 & 2 / 25 & 2 / 25 \\ 25-30 & 1 / 12 & 2 / 24\end{array}$

\section{References}

AlBerTi, LEON BATTISTA. 1966. L'Architettura (De re aedificatoria). ed. \& transl. Giovanni Orlandi, ed. and trans. Introduction by Paolo Portoghesi. Milan: Il Polifilo.

. 1972. On Painting and On Sculpture: The Latin Texts of De Pictura and De Statua.

Ed., trans., intr. and notes by Cecil Grayson. London-New York: Phaidon.

. 1988. On the Art of Building in Ten Books. Joseph Rykwert, Neil Leach and Robert

Tavernor, trans. Cambridge MA and London: MIT Press.

DinsmOOR, William Bell. 1950. The Architecture of Ancient Greece; An account of its historic

development. 3rd ed. London, New York, Toronto, Sydney: B. T. Batsford Ltd.

GOMBrich, ERNST.1972. Art and Illusion. London: Phaidon. 
Grayson, CeCil. 1960. The Composition of L. B. Alberti's 'Decem Libri De re aedificatoria'. Münchner Jahrbuch der bildenden Kunst, 3rd series, XI: 152-161.

KEMP, MARTIN. 1990. The Science of Art: Optical themes in Western art from Brunelleschi to Seurat. New Haven and London: Yale University Press.

Krautheimer, Richard. 1963. Alberti and Vitruvius. Pp.42-52 in Acts of the Twentieth International Congress of the History of Art, vol. II. New Haven: Princeton University Press.

ManetTi, ANTONiO. 1927. Vita di Filippo di Ser Brunellesco. Elena Toesca, ed. Florence. 1970. The Life of Brunelleschi. Howard Saalman, ed. Catherine Engass, trans. University Park.

Murray, PETER. 1986. The Architecture of the Italian Renaissance. Revised 3rd ed. London: Thames and Hudson.

Palladio, ANDREA. 1997. The Four books on Architecture. Robert Tavernor and Richard Schofield, trans. Cambridge MA: MIT 1997.

Pollit, J.J. 1974. The Ancient View of Greek Art: Criticism, History, and Terminology. New Haven and London: Yale University Press.

TAVERnOR, ROBERT. 1991. Palladio and Palladianism. London: Thames and Hudson.

TOBIn, Richard. 1990. Ancient Perspective and Euclid's Optics. Journal of the Warburg and Courtauld Institutes 53: 14-41.

VIla DOMINI, DaVID A. 1996. The Diminution of the Column in Alberti and Vitruvius; Concerning Optical Corrections. Edinburgh Architecture Research 23: 24-49.

. 2000. "Column Marginalia", Architectural Research Quarterly 4, 3: 286-288.

VITRUVIUS. 1955. De architectura. Frank Granger trans. 2 vols. Cambridge MA and London: William Heinemann Ltd / Harvard University Press. . 1960. The ten books on architecture. Morris Hicky Morgan, trans. New York: Dover Publications.

1987. Archîtectura. Facsimile edition of Los diez libros de archîtectura de M. Vitruvio Polión, traducidos del latin y comentados por Don Joseph Ortíz y Sanz, Madrid: Imprenta Real, 1787. Barcelona: Alta Fulla.

WitTKOWer, Rudolf. 1978. The Changing Concept of Proportion. Pp. 108-123 in Idea and Image. Studies in the Italian Renaissance. London: Thames and Hudson. Also published in Architects' Year Book V (1953) and Daedalus Lxxxix (1960).

White, John. 1956. Perspective in Ancient drawing and painting. London: The Society for the Promotion of Hellenic Studies.

\section{About the Author}

David A. Vila Domini studied architecture in Britain and Spain, and now teaches design, history and theory of architecture in Scotland. His main fields of interest are design in classical and modern architecture. 